\title{
IX
}

\section{THE ORIGIN OF THE BUDDHAVARSHA, THE CEYLONESE RECKONING FROM THE DEATH OF BUDDHA}

\author{
By J. F. Fleet, I.C.S. (Retd.), Ph.D., C.I.E.
}

A PASSAGE in the Last Edict of Aśōka, ${ }^{1}$ which is
explained by, and at the same time endorses, certain statements in the Dipavamsa and the Mahãvamsa, shows that in the third century B.C. there existed a record, of the time elapsed since the death of Buddha, from which it was known that Asóka was anointed to the sovereignty 218 years after the death. From what the two chronicles state on that point and indicate in respect of the interval between the anointment of Aśōka and the initial date of his grandfather Chandragupta, we know, by the help of the statements of the Greek writers about Chandragupta, that the death of Buddha must be placed closely about B.c. 480 . And we have arrived at the result (see p. 22 above) that the event is to be referred exactly to B.c. 483.

On the other hand, certain statements in the Suluvamsa (the continuation of the Mahāvamsa), ${ }^{2}$ along with the Ceylonese, Burmese, and Siamese chronology of the present day, show the existence, from the fourteenth century A.D., of a reckoning, known as the Buddhavarsha, which would place the death of Buddha sixty-one years earlier, in B.C. 544. The object of this article is to trace the origin of this later reckoning, and to examine some of the chronological details which have been affected by it.

In the Dipavamsa, the original reckoning, from B.c. 483, is first presented in connection with the ordination of

1 Regarding this record, see this Journal, 1908, 811.

2 See note 1 on p. 2 above. 
Dāsaka, at 16 years after the death (4. 27, 28; 5. 76, 77). The only conspicuous use of it in that work, however, is in the record of the Vaiśāli schism, at 100 years (4. 47, 48; 5. 16), which led to the Second Council; of the birth of Mahēndra, at 204 years (6. 20); of the anointment of Aśōka, at 218 years (6. 1); and, at 236 years, of the interruption of the Buddhist observances which led to the Third Council (7. 37, 44), - of the anointment of Dévannampiya-Tissa (17. 78), - and of the arrival of Mahēndra (15. 71). The reckoning does not figure in the Dipavamsa after the last-mentioned year. In the Mahāvamsa, it appears only in connection with the Vaisaali schism, at ten years of the reign of Kālāsōka and at 100 years after the death (ed. Turnour, p. 15), and with the anointment of Aśōka, at 218 years (p. 22). The latest known date in this reckoning is that of the year 256, presented in the Last Edict of Aśoka. And this is also the only known inscriptional date in it.

It is plain, in more than one way, that this reckoning from B.c. 483 was of Indian origin, and became known in Ceylon through the arrival there of Mahēndra, as an emissary of the Buddhists of India. And, taking all things together, we have every reason to believe that it was confined to esoteric Buddhist circles, and did not, either before, in, or after the time of Aśoka, commend itself for any public use. As regards India, the manner in which the other dated records of Aśoka are dated according to the number of years elapsed since his anointment to the sovereignty, shows that in his time, as indeed for nearly two centuries after him, - until the first Indian era, the so-called Vikrama era of B.c. 58, was founded by Kanishka, ${ }^{1}$ in the sense that the opening

\footnotetext{
1 Professor Lïders has shown that this name is probably written most correctly with the lingual $n$; also, that the vowel in the first syllable should perhaps be taken to be the long $\vec{a}$ : see Epigraphia Indica, vol. 9 , p. 240.
} 
years of it were the years of his reign,- no recognized Indian era existed, and the chronological system for official purposes was that of regnal reckonings. And the directions given by Aśoka in the third rock-edict, that his local representatives should make a complete tour throughout their charges every five years, are suggestive that the popular and general method of measuring time was the five-years luni-solar cycle of the Vēdānga-Jyōtisha and the Paitāmaha-Siddhānta. As regards Ceylon, there, also, the chronicles mentioned above disclose the same system of regnal reckonings. And there, also, there are, so far, no signs that the reckoning from B.c. 483 was ever adopted as a standard era, either for state purposes or even in Buddhist circles. We can, of course, only treat this matter, like so many others, on such evidence as is available: we do not know what epigraphical discoveries may be made hereafter. But the inscriptions of Ceylon have already been fairly well exploited, without any being found dated in this reckoning of B.C. 483 . And, if it was maintained, it is most extraordinary that no date in it, after that of the year 236, should be found in the Dipavamsa, in the Mahāvamsa (the commentary on the Dipavamsa), ${ }^{1}$ and in the earlier chapters of the Suluvamsa. The fact seems to be that, for many centuries, the interest of the Ceylonese centred, not in the death of Buddha, but in the introduction of Buddhism into Ceylon by Mahēndra in the year 236 expired, ${ }^{2}$ and in the local events which immediately followed; namely, the conversion of Dēvannampiya-Tissa, ${ }^{3}$ the establishment of Buddhism as the state religion, and the building of the Mahāvihāra monastery. And it seems possible that the

1 See the note on p. 5 above.

${ }^{2}$ Regarding the use of this and similar expressions, see note 1 on p. 12 above.

See p. $33 \mathrm{f}$. above. 
Ceylonese had a reckoning running from that year: see the Mahāvamsa, p. 206, where we are told that Vattagāmani (otherwise known as Valagambāhu I) built the Abhayagirivihāra at 217 years, 10 months, 10 days, after the building of the Mahāvihära. But it is equally possible that they did not maintain any particular era at that time, but arrived at that date, and at any similar ones, by adding up the figures for the reigns of their kings. In any case, no further use of a reckoning from the death of Buddha is traceable in Ceylon after the year 236, until we come to the Buddhavarsha.

The later reckoning, the Buddhavarsha or "years of Buddha", with its initial point in B.c. 544, does not figure in the Dipavamsa and the Mahāvamsa. In the Suluvamsa it is found first in chapter 90 , verses 108, 109, which say, in connection with Bhuvanēkabāhu IV : ${ }^{2}$

Tassa chatutthakē vassē Muni-nibbānatō pana

èka-sahassam khō atthha-satam hi chatur-ādhikam

navuti-samvachchhar-ātitam viññeyyam naya-dassinā ||

"It should be understood, by anyone who is looking for guidance, that at his fourth year there had passed 1894 years since the death of the Sage." 3

1 This term appears to be the standing designation of the reckoning. It is found in the inscriptions of the years 1743 and 1958 (see p. 327 below, and note 1 on p. 333). Upham used it, in writing of " the Budhu verousa or era", as quoted by Turnour in his Mahawanso, introd., p. 6. It is met with in the modern inscription at Bōdh-Gaya which is apparently dated Buddhavassē 2427, in A.D. 1884: see Cunningham, Mahäbodhi, p. 19, note 2 ; also note 1 on p. 1 above. And I am informed that it is used in Ceylonese almanacs. The term in Burma seems to be Jinachakra, 'the cycle of the Conqueror'; with reference perhaps to the 5000 years for which the religion and the era are to last.

2 For the words of the text, I am indebted to Mrs. Bode, who has kindly verified for me all the other details, also, which I quote in this article from Sumangala and Batuwantudawa's edition.

3 Subsequent instances of the use of the reckoning in the Suluvamsa are as follows: in $91.15,16$, the year 1953 ; in $92.6-8$, the year 2085 ; in $94.5,6$, the year 2135 ; in $94.19,20$, the year 2140 ; in 99.2 , the year 
As we shall see, however, the use of this later reckoning is carried back by epigraphic evidence to nearly two centuries before that time. But, even so, there remains a gap of fourteen centuries from the latest date in the original reckoning to the time for which the use of the new reckoning is established. That an appreciable error was made, in the process of starting again, after so long a period of desuetude, a reckoning from the death of Buddha, is no matter for surprise: the question is, how was that error set up?

The earliest known instance of the use of the later reckoning, with the term Buddhavarsha, "the years of Buddha," attached to it, in a record framed at the time of the date given in it, is found in an inscription at Polonnaruwa, ${ }^{1}$ which gives the exact date of the anointment of Sāhasamalla (No. 126, A.D. 1200-2, in Turnour's list of the kings of Ceylon); namely, at 1743 years, 3 months, 27 days, of the Buddhavarsha, on Wednesday, the twelfth day of the bright fortnight of the month Binara (Bhādrapada). ${ }^{2}$ It may be observed that the

2290 ; in $100.60,61$, the year 2293 ; in 100.92 , the year 2299 ; in 100. 286 , the year 2301 . In each case the dating appears to be specifically from the nibbāna or parinibbanna (according to the exigencies of the metre), i.e. the death, of Buddha.

1 Translation (apparently by Armour) in the Ceylon Almanac for 1834, p. 190, in an appendix to 'Turnour's epitome of the history of Ceylon. Text and translation by Rhys Davids in this Journal, 1875. 356. Remarks, text, and translation by Müller in Ancient Inscriptions in Ceylon, No. 156, pp. 68, 103, 136 . It is to be hoped that Mr. Wickremasinghe may see his way to giving us in his Epigraphia Zeylanica, at some early date, critical texts and translations of this and the other two inscriptions which I mention.

${ }^{2}$ Müller's translation gives Tuesday, instead of Wednesday: the translation in this Journal gives Thursday, the full-moon day. The words in the respective texts are pura dolos wak lada Bada dawas, and pura doloswak lada Bada dā. According to Alwis (Journal of the Ceylon Branch R.A.S., vol. 3, pp. 181, 191), -and his explanations have every appearance of being correct, - pura means the fortnight of the waxing moon, doloswaka means the twelfth tithi, and Bada $\bar{a} \bar{a}$ means Wednesday 
specification of the 3 months and 27 days marks the full-moon of Vaiśākha as the initial point of the years of the reckoning: ${ }^{1}$ also, that the other Polonnaruwa inscription, eited below, and the records of subsequent dates in the Suluvamsa (see p. 326 above, and note 3) show that that day was selected as being held to be the day of the death of Buddha. ${ }^{2}$

We can carry back the use of the same reckoning, though not under so specific a name, to a somewhat earlier time, by an inscription at Galpota ${ }^{3}$ of the time of Nissankamalla, who is the Kitti-Nissanka of the Suluvamsa (No. 122, A.D. 1187-96, in Turnour's list). This record recites that Vira-Nissankamalla was invited by "the king, who was his senior kinsman", to come from India and reign over Ceylon, and that Nissankamalla, having so come, was in due course anointed to

(the words for Tuesday and Thursday being 'Angaharuwādà' and 'Brahaspatindā'): and the translation in the Ceylon Almanac is in agreement with this.

1 I have not been able to learn what the present practice is on this point. Turnour, writing in 1837, seemed to mark the full-moon day of Vaiśākha as being then the initial day of the years of the Buddhavarsha (JASB, 6, 1837. 505: the figure 2480 there given is an obvious misprint for 2380). But there are some indications that the observance of the Vaiśākhapũjā (see p. 8 above) has now ceased in at any rate the northern parts of Ceylon, where the calendar year is the solar year commencing with the Mëshasamkrānti, the entrance of the sun into the sidereal Aries, occurring now on 11 or 12 April; and that the day of that occurrence is the only recognized Ceylonese New Year's Day in those parts. And Kern (Manual of Indian Buddhism, p. 101) seems to quote Pallegoix (1854) to the effect that the observance of the Vaiśăkhapūjā, though still maintained in Siam, had then already ceased in Ceylon. Perhaps someone who has a practical knowledge of Ceylon will enlighten us on this point?

${ }^{2}$ Regarding the real day, Kārttika śukla 8 , see my article at p. I ff. above.

3 Translation (apparently by Armour) in the Ceylon Almanac for 1834, p. 184 (where the inscription is said to be at Polonnaruwa). Remarks, text, and translation by Müller, op. cit., No. 148, pp. 66, 95, 128.

4 This seems to be Vijayabāhu II, No. 120, sister's son and successor of Parakkamabāhu I. He reigned for one year, commencing in A.D. 1186 or closely thereabouts. 
the sovereignty. And it puts forward the year 1700 after the time when Vijaya landed in Ceylon, as the date of (apparently) the conception of Nissankamalla. ${ }^{1}$ In explanation of these statements we may observe as follows. According to the story told in outline in the Dipavamsa, 9. 1-31, and amplified in the Mahāvamsa, pp. 43-53, Vijaya, the first traditional king of Ceylon, came from India, and landed in Ceylon on the day on which Buddha died (Dipavamisa, 9. 21-2 ; Mahāvamsa, p. 47): and so a date from the landing of Vijaya is the same with a date from the death of Buddha. ${ }^{2}$ Further, Vijaya was a great-grandson (through the daughter) of a king of Vanga (part of Bengal) and of his chief queen who was a daughter of a king of Kalinga (say Gañjām and Vizagapatam, and perhaps part of the Gōdāvarī district) : Vijaya had no son, and accordingly called a kinsman from India. to succeed him : and so there arose a custom that, whenever occasion demanded it, a king of Ceylon was obtained by summoning a descendant of the royal house of Kalinga.

And we can carry back the use of the reckoning in an inchoate and disjointed form to a still earlier time by another inscription at Polonnaruwa, ${ }^{3}$ of the time of Parakkamabāhu I (No. 119, A.D. 1153-86, in Turnour's list). This record recites that Buddha died forty-five

1 The translation in the Ceylon Almanac for 1834 takes it as the date when Nissankamalla arrived in Ceylon. But that explanation seems not possible. Müller's translation is somewhat involved, but perhaps was meant to indicate the year as the date of the conception, which it really appears to be. Vijaya did not reach Ceylon by flying through the air: he travelled by ship. But Buddha flew down from the heavens when he was conceived by Māyā: and it seems plainly to be a similar flight through the air which the inseription attributes to Nissankamalla.

${ }^{2} \mathrm{As}$, for instance, in Dipavamsa, 17. 77-8, where the question is how many years elapsed from the landing of Vijaya to the anointment of Dēvanampiya-Tissa, and the answer is that 236 years elapsed to the anointment from the death of Buddha.

${ }^{3}$ Remarks, text, and translation by Müller, op. cit., No. 137, pp. 61, $87,120$. 
years and four days after his great defeat of the tempter Māra, and then proceeds to mention the year 454 after the death in connection with Valagambāhu I (Vaț̣agāmani), -apparently called Valagam-Abhā (= Abhaya) in the record, - and to give for Parakkamabahhu I the date of 1254 years after that. Here, the year 454, which the inscription would ordinarily be understood to put forward as the initial date of Valagambāhu-Vatțtagāmani, represents 236 years for the date of the building of the Mahāvihāra by Dēvānampiya-Tissa plus 217 years, 10 months, 10 days, - treated in round numbers as 218 years, 1 for the date of the building of the Abhayagirivihāra by Vatțagāmani (see p. 326 above). ${ }^{2}$ The 1254 years added

1 It is actually so treated in the Kalyāni inscription mentioned in the next note.

2 The history given to us in the chronicles at this point is as follows: Dīpavamisa, 19. 14-20 ; 20. 14-19 ; Mahāvan்sa, pp. 202-8. Vațtagāmani reigned in the first instance for 5 months. He was then driven out by seven Damila invaders, five of whom (shown under No. 20 in my table at p. 350 below) reigned in succession for 14 years, 7 months. He then succeeded in rallying a force, by means of which he killed the last of them, Dāthika or Dāthiya, and recovered his kingdom. He then built the Abhayagirivihāra. And he reigned for 12 years from his restoration.

The details in my table place the initial date of Vattagāmani at 437 years ( 9 months, 10 days) and his restoration at 452 years ( 9 months, 10 days) according to the Mahävamsa, and 8 years earlier according to the Dipavamisa. According to both the chronicles, the year 454 fell during his reign. And the inscription may be taken as treating his restoration as the important point, with that date for it.

The Kalyāṇi inscription of A.D. 1476, from Pegu, Lower Burma, seems, as translated (Indian Antiquary, 22. 38), to go farther, and to place the initial point itself of Vatṭagāmani at the year $218(+236=454)$. But the text (p. 159) has yad $\bar{\alpha}$ pana, not tada pana; and the editor has divided and punctuated the remainder of the passage wrongly. What the record really says is as follows:- "The religion remained pure for 218 years after the building of the Mahāvihāra . . . But, when king Vatțagãmani-Abhaya conquered the Damiḷa king Dādhiya (sic) and acquired the sovereignty in Ceylon, he caused the Abhayagirivihära to be made ; and, bringing the Thëra Mahā-Tissa, — who had always been the first to befriend him during the 14 years when, having been overcome and driven away by seven Damilas, he was living in hiding, - he gave it to him :" and so (it goes on) there occurred the secession of the Abhayagirivihāra community.

The commentary on the Mahāvamsa, without going into the detail of 
to that give 1708 years as the date of the record. The inscription does not appear to state the regnal year : but, reciting various things that Parakkamabāhu I had already done to promote the Buddhist faith, especially on behalf of the community of the Mahāvihāra, it indicates plainly enough that the year was not a very early one; and the year seems to have been the thirteenth year, current.

The reckoning presented in these three records has run on to the present time. So we know how to apply it.

The year 1743, treated as the completed year in accordance with the general practice, ${ }^{1}$ takes us, for the given month, to A.D. 1200 or 1201 according as it is counted from an initial point in B.C. 544 or in 543. The given details, Bhādrapada sukla 12, Wednesday, are correct for Wednesday, 23 August, A.D. 1200. So we have the date of the anointment of Sāhasamalla as a definitely fixed point in the later chronology. Further, this result shows that, whatever may be the case now, ${ }^{2}$ when the reckoning was set going it was made to run from an initial point in B.c. 544 , not 543 .

The year 1708 completed, counted from the initial point in B.C. 544 established by the preceding result, takes us to A.D. 1165. And quite in accordance with that are the details in the Suluvamsa, 79. 87; 80. 1-31, which assign to Parakkamabāhu I a reign of thirty-three years, and place his initial point at 47 years, 6 days, before the

months and days given in the text, says that the residents of Abhayagiri seceded in the year 217 after the establishment of religion in Ceylon, and in the time of king Vatțagämani, and, under the name of Dhammaruchikas, took up their abode in the Abhayagirivihära, which he caused to be built : see Oldenberg's Catalogue of Pāli MSS. in the India Office Library, p. 114 ; also Turnour's Mahāwanso, introd., p. 53.

1 See this Journal, 1907. 1037, note 2.

2 See p. 1 f. above, and note. Since writing those remarks and these, $I$ have received information that the present Ceylonese reckoning does, like that of Burma and Siam, place the initial point in B.c. 544. 
initial point of Sāhasamalla; that is, in A.D. 1153, in the year 1696 completed. $^{\mathbf{1}}$

And the year 1700 completed takes us similarly to A.D. 1157, which is quite compatible, for the conception of Nissankamalla, with the period of his reign; namely, A.D. 1187-96, from the same details in the Suluvamsa: he would be about twenty-nine years old when he was anointed to the sovereignty. This date. it may be observed, was of course not recorded at the time of the event, but was laid down subsequently, by computation.

It is practically certain, in these circumstances, that the establishment of the new reckoning was a result of the great restoration of Buddhism which took place under Parakkamabāhu I, after an almost total extinction of it during the Tamil domination from about A.D. 1023 to virtually the commencement of his reign in A.D. $1153 .^{2}$ The Polonnaruwa inscription of Parakkamabāhu I shows the existence of a desire for such reckoning, and exhibits the reckoning in a rudimentary, disconnected shape. The Galpota inscription of Nissankamalla presents the reckoning reduced to an unbroken form, which (we can hardly doubt) had already been established in the time of Parakkamabāhu, and probably quite soon after A.D. 1165, the date of his inscription cited above. The specific name for the

1 Wijesinha placed it in A.D. 1164, in the year 1707 completed: but his chronology is particularly faulty for this period (see p. 344 below). The Kalyāni inscription of A.D. 1176 (see note 2 on p. 330 above) says (IA, 22. 39, 206) that the 18th year after the anointment of Parakkamabāhu I came 1472 years after the establishment of religion in Ceylon, and 1708 years after the death of Buddha; which would place the anointment in the year 1690 completed, in A.D. 1147-48. This is curious ; because Turnour, who 'adjusted' an 'error' of six years at this point, appears to have arrived in natural course at the year 1690 , and then to have raised the figure on the strength of a statement found in some other work. Reckoned back from the anointment of Sāhasamalla, the exact date of which we now know, the details in the Suluvamsa distinctly place the event in the year 1696 completed, in A.D. 1153.

2 See Muller, op. cit., 60 ff. ; and the steps taken by Parakkamabāhu I as narrated in the Suluvamsa, chapters 73, 74, 76 (verses 106-22), 78, and in the inscription of the year 1708 . 
reckoning, Buddhavarsha, which existed at any rate in A.D. 1200, may have been devised and applied under Parakkamabāhu : or this may have been done in the time of Nissankamalla, who reigned for nine years, and appears, both from the chronicle and from his inscriptions, to have been a good Buddhist. In any case, the Polonnaruwa inscription of Sähasamalla gives us the reckoning in full swing, as the Buddhavarsha or "years of Buddha", in A.D. 1200." And we thus arrive at the conclusion that it was towards the end of the twelfth century A.D. that the establishment of the new reckoning was effected. It is, of course, the case that books written after that time present dates in this same reckoning for earlier times: ${ }^{2}$ but it is evident that those dates were arrived at by computation, and represent intermediate totals which were made out in the process itself by which the reckoning was put together.

Now, that this reckoning with the initial point in B.c. 544 gives a large error for the anointment of Dẽvānampiya-Tissa, which it would place in B.C. 308, is undeniable: because that event came $73 \frac{1}{2}$ years after the initial date of Chandragupta, ${ }^{3}$ which cannot be placed before B.C. 325. On the other side, the reckoning presents a point of no error in A.D. 1200, in placing the anointment of Sâhasamalla in that year, shortly after the end of the Buddhavarsha year 1743. From Dēvānampiya-Tissa to Sāhasamalla, there is no abnormal reign like (on a grand scale) that of Ranāditya I of Kashmīr, to whom Kalhaṇa

1 Subsequent inscriptional instances of the use of the era are Müller's No. 160, of the "Buddhavarsha" year 1958, and No. 162, of the year 2051 of (according to the translation) "the era of the omniscient Gautama".

2 See, e.g., Turnour's Mahäwanso, introd., pp. 53, 60.

3 Namely, fifty-six years from the initial date of Chandragupta to the anointment of Aśoka, and then seventeen and a half years after that: see pp. 3, 11, above. 
had to assign three centuries, in order to make out his chronology : ${ }^{1}$ and so there is no reason for thinking that the whole error can have been introduced all at once, at any one particular point. What did occur in the making of the reckoning was as follows, as is illustrated partly by the Dipavamsa and the Mahãvamsa, partly by certain statements taken by Turnour from other works which we shall mention again farther on.

The persons who put the reckoning together had the anointment of Dēvanampiya-Tissa (No. 7 in the list) fixed at 236 years after the death of Buddha; that is, in B.c. 247. They had also, in the Dipavamsa and the Mahāvamsa, the list of their kings, with the length of the reign of each of them, from that time onwards as far as the end of the reign of Mahäsēna (No. 54): and they apparently had, for that same period, some other work or works, indicated in the commentary on the opening verses of the Mahävamsa, which gave in some respects closer details than the even years which, for the most part, are presented in the Dipavamsa and the Mahāvamsa. For the subsequent period, they of course had access to the archives from which the Suluvamisa was afterwards written as far as the time of Parakkamabāhu IV, A.D. 1295 or 1319 or thereabouts (see note 1 on p. 2 above). ${ }^{2}$ And from the materials thus available they made out details which, added to the 236 years, gave them the (supposed) number of years up to (say) the thirteenth year of Parakkamabāhu I. In doing that, they here and there laid down exact details of years,

1 A reign of fifty-five years is assigned to Vijayabāhu I, No. 115 in Turnour's list, A.D. 1071-1126: but he appears to have come to the throne early, in his seventeenth or eighteenth year. Including that, there are only twenty reigns in excess of twenty years each.

${ }^{2}$ And the archives must have contained carefully prepared genealogical tables, including exact records of births and deaths. Without such a guide, there could hardly have been written up the family details given here and there in the Suluvamsa from 57. 4 to 67.87 . 
months, and days. But for the most part they followed the lines exhibited in the chronicles: in those works there are very few cases, of reigns of one year and upwards, in which the odd months and days are given: the statements are nearly always confined to even years, and must consequently have been arrived at on some such principle as treating, for instance, 10 years and 5 months as 10 years, and 10 years and 7 months as 11 years. ${ }^{1}$ The number of cases in which the duration of reigns was increased by this process must have preponderated. Also, there are discrepancies between the Dipavanisa and the Mahāvanisa which suggest mistakes on one side or the other. At any rate, the ultimate result was that the interval from the anointment of Dēvannampiya-Tissa to the point which we have assumed, the thirteenth year of Parakkamabāhu I, was unduly raised from (B.C. 247 + A.D. 1164 =) 1411 years to $(1708-236=) 1472$ years. There were thus set back, by a constantly increasing amount, all the earlier dates, prior to the time of no error (from A.D. 1165 onwards), as far as the anointment of Dēvānampiya-Tissa. That event was set back by sixty-one years. And through this there were set back, equally, by the same number of years, three other occurrences of leading importance; namely (taken in the order in which the data lead up to the cardinal event on which the regulation of the whole of the early chronology depends), the death of Buddha, the anointment of Asooka, and the acquisition of the sovereignty by Chandragupta.

It would be very convenient if the whole excess of sixty-one years could be wiped out at some one point. But the way to doing that is not clear. On the contrary, it seems plain that that is not the remedy; but, at the

I As other instances of the obvious predilection for even years, note how, in the Kalyāni inscription (see note 2 on p. 330 above), the period of 217 years, 10 months, 10 days is stated as 218 years, and the period of 14 years, 7 months, as 14 years. 
same time, that the total error can be reduced by appreciable reductions at a few easily defined places. Up to the time of Parakkamabāhu I, Turnour made, from other "Native Histories", certain 'adjustments' and 'corrections' in the results given by the Mahāvamsa and the Suluvanina. These adjustments were as follows: two years under Abhaya-Vatțagāmani, No. 19 in my table at p. 350 below; twelve years under Mahāsēna, No. 54; one year under Ambasāmanēra-Silākāla, No. 71 in his list; four years under Silāmēgha-Sēna, No. 100; and six years in the case of Parakkamabāhu I himself. ${ }^{1}$ In each case, his adjustment has the effect, from one point of view, of pushing forward the initial point of the king's reign by the specified amount: but what it really does is to illustrate a step in the progressive antedating of the death of Buddha from B.C. 483 to 544. And these adjustments account for twenty-five years out of the total excess.

The total excess, sixty-one years, is an accumulated error, which is to be treated as a decreasing one from the time of Dēvänampiya-Tissa, and which comes to nil in or about A.D. 1165. Fourteen years of it are accounted for (as we can see above) by the commencement of the reign of Mahāsēna: the remainder is to be eliminated chiefly from about A.D. 400 onwards. ${ }^{2}$ But the whole chronology remains to be revised much more closely than has ever yet been attempted; and particularly in the light of certain synchronisms between Indian and Ceylonese history which are established by statements in Indian inscriptions and Chinese writings. ${ }^{3}$ We shall be greatly indebted to

1 I quote the figures from his first table (for which see farther on), which was the basis of his work. He subsequently reduced the twelve years under Mahāsēna to four years, by assigning some of them to previous details: but the general position was left the same.

2 See p. 342 below, under my observations on No. 55, Siri-Mēghavanna.

3 Perhaps something useful may also be found in Renaudot's Ancient Accounts of India and China by two Mohammedan Travellers who vent to those parts [and to Ceylon] in the ninth century. 
anyone who will make such a revision. Meanwhile, the following notes may be of some use.

Turnour's chronological table of the kings of Ceylon, based on the Mahāvamsa and the Suluvamsa, was issued first in the Ceylon Almanac for 1833, at p. $224 \mathrm{ff}$. $\mathrm{He}$ gave it again, revised in some respects, in the same publication for 1834 , at p. $193 \mathrm{ff}$. And he reproduced the revised table, with some improvements in the spelling of the names, in his Mahawwanso (1837), introd., p. $60 \mathrm{ff}$.

As a pioneer, Turnour did most valuable work. And we have in particular to thank him for giving us a text of the Mahāvamsa which, while it is not a critical text according to the modern standard, is the only easily readable text of this work that we so far have.

In his chronological table, he took a course which, no doubt, reasonably seemed at that time to be a safe one, but which we now know was not such : instead of adhering strictly to the details given in the Mahävamsa and the Suluvarisa, and to the totals set up by them for any particular points, he (as we have already indicated) corrected such totals at certain places by means of other totals presented by statements taken from other "Native Histories". It would be a complicated task, and it would hardly serve any useful purpose, to attempt to show in detail how and why Turnour's dates do not answer properly to those set up by the chronicles. It seems sufficient to indicate the position by what is said above, and to add that he did not always extract the details from his text correctly, and that his adjustments do not anywhere help to reduce the excess of sixty-one years which attaches to the reckoning from B.c. 544: on the contrary, they always increase, instead of diminishing, the supposed number of years elapsed from the death of Buddha up to any given point.

We may possibly commence correcting the Mahāvamisa 
or the Dipavamina or both by means of extraneous statements, when we know exactly the source and nature of those statements, and so find ourselves in a position to appraise the value of them. Meanwhile we may note that no work, presenting any such statements, appears to have been written until after the establishment of the Buddhavarsha reckoning; that is, until nearly seven centuries after the time when even the Mahāvamsa was composed. There is at least no primâ-facie reason for attaching more value to statements of that late period than to the Dipavamsa and the Mahãvamsa themselves. And any value which such statements may possess is further weakened by the obvious fact that they represent stages in the process itself by which the erroneous reckoning was arrived at.

What we need first, to start a final inquiry into the Ceylonese chronology, is a table showing exactly what figures the Dipavamsa and the Mahävamsa, also the Suluvamsa for the subsequent period, really present. And I give at p. 350 below such a table for the period which I have had to examine in order to determine more satisfactorily the dates of the two earlier chronicles and of Buddhaghōsha; namely, for the time from DēvānampiyaTissa to Dhātusēna. ${ }^{1}$

In my table, I follow the numbering presented by Turnour: it may be recast hereafter, because, for instance, there is no apparent reason why the five Damilas who interrupted the reign of Abhaya-Vatțagamani (Nos. 19 and 21), and who ruled one after the other, should not receive separate numbers, instead of being grouped

1 The table might be improved by adding the relationships between the kings, and their capitals, and showing how each reign came to an end, whether by natural death, or by assassination, etc. : also, following Turnour still farther, by adding a column of remarks, exhibiting the achievements assigned to each king and the events placed in his reign. But we are concerned here with only the names, and the length of each reign. 
together as No. 20 ; but it makes matters simpler, for present purposes, to adhere to Turnour's numbering. I quote, for the length of each reign, the Dipavamsa by chapter and verse as given in Oldenberg's text and translation, and the Mahāvamsa according to the pages in Turnour's Mahäwanso, which gives both text and translation, and in Wijesinha's revised version (1889) of Turnour's translation, in which he has usually corrected, but in some cases has repeated, Turnour's mistakes. Discrepancies in figures between the two chronicles will be found under Nos. 11, 17, 35, and 47, and between Nos. 18 and 19,24 and 25, and 32 and 33: also under Nos. 39 and 42 , if we should take certain readings for the Mahāvamsa which I have not adopted. I show in thick type a few names to which special importance attaches; and the preceding totals, similarly shown in thick type, give in each case the number of years after the death of Buddha at which the king so marked is found to have commenced to reign: in applying such totals, up to 482 or 543 deduct them from 483 or 544 , and from 483 or 544 onwards deduct 482 or 543 from them; this gives the Julian year, B.C. or A.D., in which the year of the Indian or the Ceylonese reckoning ends. As an accompaniment to the table, I give certain remarks on some of the entries in it. Some more special comments are as follows.

There is no warrant for the often made assertion that we have a correct chronology, as presented to us by Turnour, from B.c. 161 as the initial date of AbhayaDutṭhagāmani, No. 14 in my table. The position is incompatible with the point that three generations had intervened between him and No. 7, Dēvānampiya-Tissa: he was the great-great-grandson of Mahānāga, younger brother of Dēvānampiya-Tissa. Moreover, the supposed reliable date for it is not correct even in itself. With 
B.c. 307 for the anointment of Dēvānampiya-Tissa, as deduced by Turnour from the initial point placed by him in B.c. 543, the details given in the Dipavamsa place the initial date of Duṭthagāmani in B.C. 171 (not in 161), and the details given in the Mahàvamsa place it in B.C. 163. With B.c. 247 as the real date of the anointment of Dēvānampiya-Tissa (see p. 27 above), which brings the end of his reign to B.C. 207 , the same details, which give an interval of 104 years according to the Mahāvamsa, or 96 years according to the Dipavamsa, place the initial date of Dutthagāmani in B.c. 103 or in 111 respectively. There is, indeed, perhaps something questionable in the intervening history, for the following reasons. No. 8, Uttiya, No. 9, Siva or Mahāsiva, No. 10, Sūra-Tissa, and No. 12, Asēla, are all represented as younger brothers of Dēvannampiya-Tissa. The reign of Dēvānampiya-Tissa was a fairly long one, 40 years. Yet we find Asēla commencing to reign according to the Dipavamsa 42 years, according to the Mahāvamsa 50 years, later. The father, Muțasiva, died in the year in which Dēvānampiya-Tissa began to reign. Consequently, Aséla was not less than 81 years old, and may have been 89, when he came to the throne. However, that affects only the intervening history, in respect of which we should perhaps note that a footnote given by Oldenberg below Dipavamsa, 18. 47, 48, indicates that all the Sinhalese MSS. of that work omit No. 11, Sēna and Guttaka, and No. 12, Asēla. On the other hand, however, we may also note that No. 10, Süra-Tissa, is indicated as long-lived; the Mahāvamsa says (p. 127) that he was a sincere worshipper of the "three gems" for 60 years before and during his reign: again, an interval of 140 or 146 years between some point in the time of Dēvānampiya-Tissa and a point in the time of Dutthagāmani is expressly stated elsewhere in the Mahãvamsa (p. 162), in the "prophecy" about the building of the 
Mahāthūpa. ${ }^{1}$ An interval of only 46 years - B.C. 207 to 161 - between Dēvānampiya-Tissa and Duṭthagāmani is wholly insufficient for the generations. But, even if the intervening details are not quite correct, cases could easily be adduced supporting either the interval of 96 years given by the Dipavamsa, or even that of 104 years given by the Mahāvamsa.

The Dipavamsa ends with the end of the reign of Mahäsenna. No. 54 in the table. According to the details laid out by Turnour for the previous reigns in his first table, the initial date of Mahäsēna should have come at 806 years after the death of Buddha, and the end of his reign at 833 years; just as we have the figures, but only by a coincidence, in my table. Turnour, however, adjusted the date of this king by pushing on his accession by twelve years to the year 818 , and placing his death at 844 years, 9 months, 20 days. It seems to have occurred to him, subsequently, that this was a somewhat violent correction: and so, in his revised table, while retaining the same figures for Mahāsēna, he recast his preceding details in such a manner as to reduce the adjustment here to four years. He thus left the reign of Mahāsēna at the years 818-45, representing (from B.C. 544) ${ }^{2}$ A.D. 275-302. And, taking his figures as being in strict accordance with the statements in the Mahàvamsa, I added to that the correction of fifty-eight (for sixty) years, and so arrived at "about A.D. 360" for the end of the Dipavamsa : see this Journal, 1906. 894. But we now see that the details in the Mahāvamsa really place the end of the reign of Mahāsēna at 833 years, which (from B.C. 483) takes us to A.D. 351 ; the details in the

1 Turnour's text has chhchattalissa: his translation gives "fifty-six" (sic), which Wijesinha altered into "forty". Are we to read chattālissa, or chhachattālizsa with one syllable in excess from the metrical point of view ? - [On this point, see now p. 355 below.]

2 See a remark in note 1 on p. 1 above. 
Dipavamisa placing it three years later. For the present, we may regard A.D. 350 as approximately the point at which the Dipavamsa comes to an end: and this and the following results for Buddhaghōsha and the Mahāvamina should be substituted for those previously given by me from Turnour's bases.

Siri-Mëghavaṇna, No. 55 in the table, is of considerable interest to us, because M. Sylvain Lévi has shown, from Chinese sources, ${ }^{1}$ that he was a contemporary of the great Samudragupta, king of Northern India, to whom he sent presents. Turnour, in consequence of the correction of twelve years which he made in connection with No. 54, Mahāsēna, pushed on the inital date of Siri-Mēghavaṇna from 833 to 845 years after the death of Buddha, and so (with B.C. 544) arrived at A.D. $302-30$ as the period of his reign. Wijesinha altered that into A.D. 304-32. And it has been proposed to adjust matters to that position by assuming A.D. 326 as the initial date of Samudragupta ${ }^{2}$ leaving only six or seven years for the reign of his father and predecessor Chandragupta I, who founded the Gupta dynasty in A.D. 319-20. The figures actually yielded by the Mahãvamsa, 833-61, reckoned from B.c. 544 in accordance with the point of view of Turnour and Wijesinha, give for Siri-Meghhavanna the period A.D. 290318; which hardly endorses the above-mentioned treatment of Samudragupta. Reckoned, however, from B.C. 483, the same figures give the period of Siri-Méghavaṇna as A.D. 351-79, - the Dipavamsa placing him three years later; which results exactly match the period, A.D. 335 or 340 to 380 , which we may more reasonably assign to Samudragupta. In connection with this case the following point may be brought out. Suppose we take it that Turnour's figures, the years $845-73$, are correct, instead

1 Journal Asiatique, 1900, pt. i, pp. 316 f., 401.

${ }^{2} \mathrm{~V}$. Smith, in Indian Antiquary, 1902. 258, 260; Early History of India, 2nd edition, 272, 308. 
of the years $833-61,=$ A.D. $351-79$, which we have from the Mahāvamsa. Then, applying them to B.C. 483, we have for Siri-Megghavanna the period A.D. 363-91, which would no doubt be possible, but on the whole is certainly too late, for the relations between him and Samudragupta. The position shows that the accumulated error up to this point, presented in the other "Native Histories", amounts to closely about the fourteen years which are represented by Turnour's adjustments, from those sources, of two years under No. 19, Vatțagāmani, and twelve years under No. 54, Mahāsēna (see p. 336 above). The balance, about forty-seven years, has to be eliminated after this period.

Buddhaghōsha was in Ceylon in the time of king Mahānāma, No. 59 in the table. Turnour gave for the limits of this reign, the years $953-75,=$ (from B.C. 544) A.D. 410-32: whence, adding sixty years, I arrived at "about A.D. 470-90": see this Journal, 1906. 903. But the details in the Mahāvamsa really place this reign at the years $941-63,=$ (from B.c. 483 ) A.D. $459-81$. The same details, applied to the figure of the Dipavamsa for the end of the reign of Mahäsenna, place the reign of Mahānāma three years later. Taking the extreme range A.D. 459 to 484 , we may for the present regard A.D. 470 as marking approximately the time when Buddhaghōsha was in Ceylon.

The Mahāvamsa was written in the time of king Dhātusèna, No. 64. For the limits of this reign, Turnour gave the years $1002-20,=($ from B.C. 544) A.D. 459-77: whence, adding sixty-one (for sixty) years, I arrived at "about A.D. 520-40" (this Journal, 1907. 341). The details in the Mahávamsa, however, really place this reign at the years $993-1011,=($ from B.C. 483) A.D. 511-529. The same details, applied to the figure of the Dipavanisa for the end of the reign of Mahāsēna, place the reign of Dhātusēna three years later. With the extreme range 
A.D. 511 to 532 , we may for the present place the writing of this work at approximately A.D. 520.

Wijesinha has assigned to Parakkamabāhu I (No. 127 in his list: The Mahāvansa, preface, p. 24) the period A.D. 1164-97. Using thereafter precisely the same details with Turnour, he has assigned to the first reign of Lìlāvati (his No. 134; Turnour's No. 125), the predecessor of Sāhasamalla, three years from A.D. 1208, against Turnour's three years from A.D. 1197. It would follow that Wijesinha should have assigned to Sāhasamalla (his No. 135), who reigned for two years, the period A.D. 1211-13, against Turnour's A.D. 1200-2. But, using the date of the Buddhavarsha year 1743, given in the Polonnaruwa inscription (see p. 331 above), which places the anointment of Sāhasamalla in A.D. 1200, he has said "error eleven years; adjusted accordingly"; and, following Turnour in showing the period of Sāhasamalla as A.D. 1200-2, he has gone on with a fresh start from that point, but has not evinced any desire to look back and adjust the preceding reigns in accordance with that position. I draw attention to this by way of indicating that Wijesinha's arrangement of the chronology is not to be accepted as final any more than Turnour's, and in at least some cases is not as good as Turnour's.

The reckoning with the initial point in B.C. 544 having been introduced into Siam and Burma from Ceylon, it will give correct results for those countries only from the time when it was taken into use in them; and the Burmese and Siamese chronologies have to be revised on the same lines with the chronology of Ceylon. For instance, it appears (see this Journal, 1908. 1115) that, according to the Burmese chronicles, Srikshētra or Prome was founded by a king Duttabaung 101 years after the death of Buddha: the date of this event will be, not B.c. 442 , as there stated, but B.c. $382-81$. 
I must leave to others the decision as to when the new reckoning was adopted in Burma and those parts. But I may draw attention to a passage in the Kalyāni inscription of A.D. 1476 from Pegu, Lower Burma (see note 2 on p. 330 above), which gives the following recital. ${ }^{1}$ Parakkamabāhu I purified the religion in Ceylon in the Sakkarāj year 526 (expired), = A.D. 1164-65. Six years later, in the year 532 (expired), = A.D. 1170-71, the Mahäthēra Uttarājiva, the preceptor of the king of Arimaddanapura, otherwise called Pugāma, that is, Pagān in Upper Burma, visited Ceylon, taking with him a Sāmanēra named Chhapața. Uttarājīva returned to Pugāma after no long time. But Chhapata remained in Ceylon for some ten years or so, to master the Tripitaka and its Atthakathā. When Chhapata, who had mean while himself become a Mahāthēra, returned to Pugāma, he found that Uttarājiva had just died, and that the priests of the Maramma country had become lords of the church in his place. Unwilling to associate with them, Chhapata, with the help of four Theras whom he had taken with him from Ceylon, founded a separate church. And so (we are told) in the Sakkarāj year 543 (expired), = A.D. 1181-82, the religion from Ceylon, as distinguished from the Buddhism which had previously been introduced from the Rāmañña country, was established at Pugāma. It may well be that the use of the new reckoning in Burma was introduced by Uttarājiva, and was perpetuated by Chhapata: their visit to Ceylon came just after the invention of it, and when it was of course an attractive novelty.

The reckoning with the initial point in B.C. 544 did not obtain any general recognition in India; because, when it was devised, Buddhism had practically died out there, except at Bōdh-Gayā. But, as there seems to have been

1 Indian Antiquary, 22 (1893). 17, 29 f. ; text at $151 \mathrm{ff}$. 
constant intercourse between Bōdh-Gaya and Ceylon, as well as other foreign countries, we should not be surprised to find occasional instances of its use at that place. ${ }^{1}$ And a case can, I think, be adduced.

From a temple at Bōdh-Gayā, which is now a temple of the sun but shows indications of being by origin a Buddhist building, we have an inscription which was edited by Pandit Bhagwanlal Indraji in the Indian Antiquary, vol. 10 (1881). 342. It recites that a prince named Purushōttama made a gandhakutì or 'perfume-chamber' of Buddha. Also, that an ascetic named Dharmarakshita, who appears to have been the superintendent of the gandhakuti, made some addition to the building. And further, that, "the religion of the Sage having decayed," either Dharmarakshita or Purushōttama (the text is not clear on this point) bowed down to, and induced or obtained the approval of, Aśokavalla, king of the Sapādalaksha mountains (the territory of the Siwälik Hills), and a Chhinda chief whose name is not given, and effected a wonderful restoration of the faith. The final verse tells us that the record was written by Indranandin, and engraved by Rāma. And next after that there comes a date; the year 1813 after the death of Buddha, Kārttika vadi 1 , Wednesday.

It was known that a king Aśōkavalla reigned at some time about A.D. 1170-90. Applying the year 1813 to an initial point in B.C. 638, which is said to be a Peguan and Chinese date for the death of Buddha, the Pandit arrived at A.D. 1176 as the probable date of the record. And Professor Kielhorn, who subsequently examined the date, found that, with Kärttika taken as the amānta month, ending with the new-moon, the given details are correct for Wednesday, 20 October, A.D. 1176: see Epigraphia Indica, vol. 5, appendix, p. 79, No. 575 .

1 I mean, of course, apart from modern instances such as that of the year 2427 , in A.D. 1884 : see note 1 on p. 326 above. 
According to the usual rules of interpretation, the given date should be a date for the Aśokavalla who is mentioned in the record. It is quite possible that B.C. 638 may be one amongst the many dates that have been set up for the death of Buddha. And it is also quite possible that, if this date does exist and was evolved before A.D. 1176, it may have found its way to Bōdh-Gayā by that time. But no indication of such a date is found in the Kalyāni inscription of A.D. 1476 (see note 2 on p. 330 above) which comes from Pegu, or in the Pô-ü-daung Hill inscription of A.D. 1774 (IA, 22. 1) from the neighbourhood of Prome, which also is in the Pegu Division of Lower Burma: these records present the reckoning from B.c. 544. And the coincidence of the figures suggests the possibility that the writers who brought this date to notice have made some confusion between B.C. 638 and A.D. 638, the initial year of the Sakkarāj or common era of Burma, which again, but on insufficient grounds, has been supposed to be of Chinese origin. Also, the use of the amānta month seems peculiar for the period and locality of the record.

Treating this date as a date in the reckoning of B.c. 544, and taking Kärttika as the pūrnimāntu month, ending with the full-moon, which is what we should expect, I find that the given details are correct for Wednesday, 1 October, A.D. 1270. This result is at least as good in itself as is the result in A.D. 1176. And it gives, in my opinion, the real date of the record. The bearing of it may be applied according to one or other of two alternatives. Either it is only the date on which the record was written and engraved; in which case, the record commemorates past occurrences, not synchronous ones: but instances of this are extremely rare; in fact, I can only cite one apparent case, the Dudhpani rock inscription (EI, 2. 345; see 344, and note 8): and there is another difficulty, indicated below. Or the Asokavalla of this record is a second king of the same name. In connection 
with the latter alternative, the following observations may be made.

We have altogether four inscriptions in which the name Aśōkavalla is found :-

(1) Our Bōdh-Gayā inscription of the year 1813. This is a Buddhist record. But there is nothing in it to show that its king Aśōkavalla was himself a Buddhist.

(2) Another Bōdh-Gayã inscription (JBBRAS, 16. 358), dated in the Lakshmaṇasena year 51, in A.D. 1171. ${ }^{1}$ This, again, is a Buddhist record. And it marks its king Aśōkavalla as a Buddhist, by describing him as a paramōpāsaka and a Mahāyānist.

(3) Another Bōdh-Gayā inscription (IA, 10. 346), dated in the Lakshmanasēna year 74, in A.D. 1194. This, also, is a Buddhist record. It mentions a prince Daśaratha, younger brother of Aśokavalla king of the Khasa people of the Sapādalaksha mountains. And it marks either Daśaratha or Aśokavalla (most probably the former) as a Jain, by describing him as "a bee at the pollen of the water-lilies which are the feet of Jinendra". The gift registered by it was made by a Buddhist follower or dependant of Daśaratha.

(4) A short inscription, not dated (IA, 10. 345), from Gōpēśvara in Garhwāl, that is, in the Siwālik territory. This seems to unmistakably mark its king Aśokavalla, whom it mentions as having just made a digvijaya, 'a tour of conquest' or 'a triumphal state progress', as a Śaiva; because it tells us that " he brought this weapon of Mahādēva (Siva) in the form of a column ",- by which it means the metal trident on which the inscription was incised,_ " and set it up as a pillar of victory."

In No. 2 (of A.D. 1171) there is nothing to suggest that the religion of Buddha had fallen into decay, as

1 There is a question regardıng the ınitıal point of the Lakshmanasena era. But it is only a matter of a few years. I follow Professor Kielhorn, who placed it in A.D. 1119 , against 1105 to 1109 . 
is stated in No. 1, our inscription of the year 1813 (hitherto understood to be of A.D. 1176). Also, none of the other names mentioned in our inscription are found in Nos. 2 and 3. And it seems to me that the Asókavalla of our inscription is distinct from the Aśokavalla of those two records, and is to be taken as a later king and identified with the Asookavalla of No. 4. If so, then in the fact that he was a Saiva we find the reason why Dharmarakshita or Purushottama had to bow down to him, and obtain his approval, before taking measures to revive the Buddhist faith.

\section{Remarks on the Table at pp. 350-1 below.}

1.- No. 9.- The Dippavamsa gives the name as Siva or Siva: the Mahāvamisa gives Mahās̄̄va.

2.- No. 10 : Süra-Tissa.-M. says that before his accession he was known as Suvannapinda-Tissa.

3.- No. 11 : Sēna and Guttaka. - D. says durẽ dvãdasa vassäni, which can only mean "the two (together) for twelve years", as taken by Oldenberg. M. says duvē visati vassāni, according both to Turnour's text and to that given us by Sumangala and Batuwantudawa. Turnour translated this as meaning "for twenty-two years": and Wijesinha repeated that translation. We can conceive it possıble that duve visati, 'two (and) twenty,' might in special circumstances - to illustrate a contrast between twenty-two and twenty-three, for instance-- be used in the place of dvāvisa or drīvisati. But there is no such occasion here: it is foreign to the language of the Mahāvamsa, to use such an expression for ordinary purposes: and we can only take duve vìsati vassāni as meaning "the two (together) for twenty years". We might perhaps compromise matters by amending both the texts into duve dvāvisa vassāni ; taking $d v \bar{a}$ from D., and adopting $v \bar{i} s a$ from M. That, however, would be only a conjecture; and I have reasons for believing that at least one manuscript of even M. gives dvaddasa: also, there is the objection that we require (see p. 340 above) to keep as small as possible, not to increase, the interval between Dēvānampiya-Tissa and No. 12, Asēla. We must wait for more reliable readings, from a further collation of manuscripts, before we can consider this and some other discrepancies to any definite end. Meanwhile, we are concerned here with what the available texts actually say.

Except for visati in the place of dvädasa, M. gives here exactly the half verse which stands in D.: duvē dvādasa vassäni rajjam dhammēnu kãrayum. I mention this because such cases seem to bear out my point that Mahānāma composed the Mahāvamisa as a commentary on the 
EARLY KINGS OF CEYLON

\begin{tabular}{|c|c|c|c|c|c|c|c|c|c|}
\hline \multirow{2}{*}{ No. } & \multirow{2}{*}{ Name. } & \multicolumn{3}{|c|}{ DīPavamsa. } & \multicolumn{5}{|c|}{ MAHĀVAM̀sa. } \\
\hline & & r. & M. D. & 0 . & Y. I & M. & & T. & W. \\
\hline & After the death of Buddha. & 236 & & 17. 78 & $(236$ & 0 & & & \\
\hline 7 & Dèvānaḿniya-Tissa . . & 40 & & 17.92 & 40 & 0 & 0 & 124 & 79 \\
\hline 8 & Uttiya. : . & 10 & 00 & 17. 93 & 10 & 0 & 0 & 126 & 81 \\
\hline 9 & Siva, Sìva, or Mahāsiva ${ }^{1}$. & 10 & & 18. 45 & 10 & 0 & & 127 & 81 \\
\hline 10 & $\begin{array}{c}\text { Sūra-Tissa, Suvannapinda- } \\
\text { Tissa }^{2} \text {. }\end{array}$ & & & & & & & & \\
\hline 11 & Sēna and Guttaka ; Damilas ${ }^{j}$ & $\begin{array}{l}10 \\
12\end{array}$ & $\begin{array}{ll}0 & 0 \\
0 & 0\end{array}$ & $\begin{array}{l}18.46 \\
18.47\end{array}$ & $\begin{array}{l}10 \\
20\end{array}$ & 0 & $\begin{array}{l}0 \\
0\end{array}$ & $\begin{array}{l}127 \\
127\end{array}$ & $\begin{array}{l}81 \\
82\end{array}$ \\
\hline 12 & Asēla . . . . . . . . . & 10 & 00 & 18. 48 & 10 & 0 & 0 & 128 & 82 \\
\hline \multirow[t]{2}{*}{13} & \multirow{2}{*}{ Elāra; a Damila ${ }^{4}$. : . } & 44 & $0 \quad 0$ & \multirow[t]{2}{*}{ 18. 49} & 44 & 0 & 0 & \multirow[t]{2}{*}{128} & \multirow[t]{2}{*}{82} \\
\hline & & 372 & 0 0 & & 380 & 0 & 0 & & \\
\hline 14 & Abhaya-Dutțhagāmani ${ }^{5}$ & 24 & 00 & 18. 54 & 24 & $\mathbf{0}$ & 0 & $196-7$ & $125-6$ \\
\hline 15 & Saddhā-Tissa . . & 18 & 00 & 20. 7 & 18 & 0 & 0 & 200 & 128 \\
\hline 16 & Thūlathana, Thullatthanaka ${ }^{6}$ & & 110 & 20. 8 & & & 10 & 201 & 128 \\
\hline 17 & Lañja- or Lajji-Tissa ${ }^{7}$ & 9 & 60 & 20.9 & 9 & 8 & 0 & 202 & 129 \\
\hline \multirow[t]{3}{*}{18} & \multirow{3}{*}{ 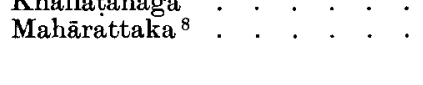 } & 6 & $0 \quad 0$ & \multirow{3}{*}{$\begin{array}{l}20.12 \\
20.13\end{array}$} & 6 & 0 & 0 & 202 & 129 \\
\hline & & & & & & & & \multirow[t]{2}{*}{202} & \multirow[t]{2}{*}{129} \\
\hline & & 428 & 711 & & 437 & 91 & & & \\
\hline 19 & Abhaya Vatţagāmani; alsocalled & & & \multirow{3}{*}{20.14} & & & & \multirow{3}{*}{202} & \multirow{3}{*}{129} \\
\hline & Valagambāhu: see also No. $21^{9}$ & \multirow{2}{*}{\multicolumn{2}{|c|}{0}} & & & $\mathbf{5}$ & $\mathbf{0}$ & & \\
\hline \multirow{7}{*}{20} & \multirow{2}{*}{ Five Damilas: ${ }^{10}$ - . . . . . } & & & & & & & & \\
\hline & & 3 & 0 & 20.15 & 3 & 0 & 0 & 204 & 130 \\
\hline & Bāhiya. . & 2 & 00 & 20. & 2 & 0 & 0 & 204 & 130 \\
\hline & 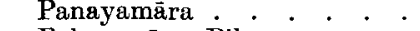 & 7 & $\begin{array}{ll}0 & 0\end{array}$ & 20.16 & 7 & 0 & 0 & 204 & 130 \\
\hline & Palayamāra, Pilayamāra . . & & 70 & 20.16 & & 7 & 0 & 204 & 130 \\
\hline & Dāṭhiya, Dāṭhika . . . . & 2 & 00 & 20.17 & 2 & 0 & 0 & 204 & 130 \\
\hline & & 444 & 711 & & 452 & 91 & & & \\
\hline 21 & Abhaya-Vattagāmani, Vala- & & & & & & & & \\
\hline 22 & $\begin{array}{l}\text { Mahāchūli-Mahātissa } 12 . \\
\text { 12. }\end{array}$ & 14 & $\begin{array}{ll}0 & 0 \\
0 & 0\end{array}$ & 20.19 & 14 & 0 & 0 & $208-9$ & $\begin{array}{l}132 \\
133\end{array}$ \\
\hline 23 & Chôra-Nāga. . . & 12 & 0 & 20.24 & 12 & 0 & 0 & 209 & $\begin{array}{l}133 \\
133\end{array}$ \\
\hline 24 & Tissa . . . & 3 & 00 & 20.25 & 3 & 0 & 0 & 209 & 133 \\
\hline & Siva ${ }^{13}$. & 1 & 20 & 20.26 & 1 & 2 & 0 & 209 & 133 \\
\hline & Vatuka ; a Damla. & $\mathbf{1}$ & 20 & 20.27 & 1 & 2 & 0 & 209 & 133 \\
\hline & 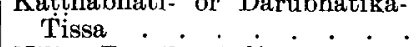 & 1 & 10 & 20.28 & 1 & 1 & 0 & 209 & 133 \\
\hline & Niliya-Damilarāja ${ }^{14}$. & & 30 & 20.29 & & 6 & 0 & 210 & 134 \\
\hline 25 & Anulā . . . . . . & & 40 & 20.30 & & 4 & 0 & 210 & 134 \\
\hline 26 & Kutikaṇna- or Kālakaṇni-Tissa & 22 & 00 & 20.35 & 22 & 0 & 0 & 210 & 134 \\
\hline 27 & Abhaya, Bhātikābhaya . & 28 & 00 & 21.30 & 28 & 0 & 0 & 210 & 134 \\
\hline 28 & Mahādāțhika-Nāga, Mahänäga & 12 & 00 & 21. 33 & 12 & 0 & 0 & 213 & 136 \\
\hline 29 & Abhaya-Āmandagāmani ${ }^{15}$. & 9 & 80 & 21.37 & 9 & 8 & 0 & 215 & 137 \\
\hline 30 & Kanirajānu- or Kanijāanu-Tissa ${ }^{16}$ & $\mathbf{3}$ & 00 & 21. 38 & 3 & 0 & 0 & 215 & 137 \\
\hline 31 & Chülābhaya & 1 & 00 & 21. 40 & 1 & 0 & 0 & 216 & 138 \\
\hline 32 & Sĩvalì-Rēvatī ${ }^{17} \cdot \ldots \cdot \cdot \cdot \cdot \cdot$ & & 40 & 21.41 & & 4 & 0 & 216 & 138 \\
\hline & $\begin{array}{l}\text { Interregnum, during which the } \\
\text { government was in the hands }\end{array}$ & & & & & & & & \\
\hline & of the Lambakannas & & & & 3 & 0 & 0 & 217 & 138 \\
\hline & & 565 & 711 & & 577 & & 10 & & \\
\hline
\end{tabular}




\begin{tabular}{|c|c|c|c|c|c|c|c|c|c|c|c|c|}
\hline \multirow{2}{*}{ No. } & \multirow{2}{*}{\multicolumn{4}{|c|}{ NamE. }} & \multicolumn{3}{|c|}{ Dīpavamsa. } & \multicolumn{5}{|c|}{ MAHĀVAìsA. } \\
\hline & & & & & Y. & M. D. & 0. & $\mathbf{Y .}$ & M. 1 & & $\mathrm{~T}$. & W. \\
\hline & & & & & 565 & 711 & & 577 & 01 & & & \\
\hline 33 & Ilanāga $^{18}$ & & . . & . . & 6 & 00 & 21. 43 & 6 & 0 & 0 & 218 & 139 \\
\hline 34 & Chandamukha-Siva & & . . & . & 8 & 70 & 21. 45 & 8 & 7 & 0 & 218 & 139 \\
\hline 35 & Yasalāla-Tissa ${ }^{19}$ & & . . & . . & 8 & 70 & 21. 46 & 7 & 8 & & 218 & 139 \\
\hline 36 & Subharāja . & & ( & . & 6 & 00 & 21. 48 & 6 & 0 & & 219 & 140 \\
\hline 37 & Vasabha; a Lamba & aka & $\operatorname{lnna}^{20}$ & & 44 & 00 & 22. 11 & 44 & 0 & 0 & 222 & 142 \\
\hline 38 & Van̉kanāsika-Tissa & & & 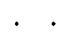 & 3 & 00 & 22. 12,27 & 3 & 0 & 0 & 223 & 142 \\
\hline 39 & Gajābāhukagāmani & & & . & 22 & 00 & 22. 14,28 & 22 & 0 & 0 & 223 & 142 \\
\hline 40 & Măhallanāga ${ }^{22}$. & & & . & 6 & 00 & 22. 17,29 & 6 & 0 & 0 & 224 & 143 \\
\hline 41 & Bhātu- or Bhātika- & Tis & $28 a^{23}$ & . & 24 & 00 & 22. 22,30 & 24 & 0 & 0 & 224 & 143 \\
\hline 42 & Kanittha-Tissa ${ }^{24}$ & & & . . & 18 & 00 & $22.25,31$ & 18 & 0 & 0 & 225 & 143 \\
\hline 43 & Khujjanāga, Chūla & inäg & $\mathrm{ga}^{25}$ &.$\quad$. & 2 & 00 & 22. 26,32 & 2 & 0 & 0 & 225 & 144 \\
\hline 44 & Kuñjanāga, Kuḍda & näg & ga 26 & . & 1 & 00 & $22.26,33$ & 1 & 0 & 0 & 225 & 144 \\
\hline 45 & Sirināga I & & & . . & 19 & 00 & $22.34,36$ & 19 & 0 & 0 & 226 & 144 \\
\hline 46 & Tissaka, Vōhāraka & Tis & $\operatorname{ssa}^{27}$ & . . & 22 & $\begin{array}{ll}0 & 0\end{array}$ & 22.45 & 22 & 0 & 0 & 226 & 144 \\
\hline 47 & Abhaya, Abhayanä & $\mathrm{ga}^{2}$ & & . & 22 & 00 & 22. 38 & 8 & 0 & 0 & 228 & 145 \\
\hline 48 & Sirinăga II & & 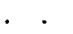 & . & 2 & $\begin{array}{ll}0 & 0\end{array}$ & 22. 46 & 2 & 0 & 0 & 228 & 145 \\
\hline 49 & Vijayakumāraka ${ }^{29}$ & & & . & 1 & & 22. 51 & 1 & 0 & 0 & 228 & 145 \\
\hline \multirow[t]{2}{*}{50} & Asanga- or Samghs & a-Ti & issa ; & ; a & & & & & & & & \\
\hline & Lambakanna & & & . & 4 & $0 \quad 0$ & 22. 52 & 4 & $\theta$ & 0 & 229 & 146 \\
\hline \multirow{2}{*}{$\begin{array}{l}51 \\
52\end{array}$} & Samighabōdhi ; a I & Lam & nbaka & anna. & 2 & 00 & 22. 53 & 2 & 0 & 0 & 229 & 146 \\
\hline & $\begin{array}{c}\text { Abhaya-Mëghavan } \\
\text { bhaya : a Lamb }\end{array}$ & na, & $\begin{array}{l}\text { Gōthe } \\
\text { unna }\end{array}$ & & 13 & & 22. 60 & 13 & & & 231 & 148 \\
\hline \multirow[t]{2}{*}{53} & Jettha-Tissa ${ }^{32}$. & $\cdot$ & $\because$ & : & 10 & $\begin{array}{ll}0 & 0 \\
\end{array}$ & 22.65 & 10 & 0 & 0 & 234 & 149 \\
\hline & & & & & 809 & 911 & & 806 & 31 & & & \\
\hline \multirow[t]{2}{*}{54} & Mahāsēna & . & - & . & 27 & 00 & 22. 66 & 27 & $\mathbf{0}$ & $\mathbf{0}$ & 234 & 149 \\
\hline & & & & & 836 & 911 & & 833 & 31 & & & \\
\hline $\mathbf{5 5}$ & Siri-Mēghavañna 33 & & . & & & & & 28 & 0 & & 242 & 154 \\
\hline 56 & Jettha-Tissa . & . & . & . & & & & 9 & 0 & & 242 & 154 \\
\hline 57 & Buddhadāsa . & . & . . & . . & & & & 29 & 0 & & 247 & 158 \\
\hline \multirow[t]{3}{*}{58} & Upatissa. . & . & . . & . & & & & 42 & 0 & & 250 & 160 \\
\hline & & & & & (108 & $\left.\begin{array}{ll}0 & 0\end{array}\right)$ & & 108 & 0 & & & \\
\hline & & & & & $(\overline{944}$ & $911)$ & & 941 & 31 & 10 & & \\
\hline & Mahänäma . & & & & & & & 22 & $\mathbf{0}$ & 0 & 253 & 162 \\
\hline 60 & Sotthisēna ${ }^{34}$. & . & . & • & & & & & & 1 & 253 & 162 \\
\hline 61 & Jantu ${ }^{35}$ & $\cdot$ & . . & . & & & & $\mathbf{l}$ & 0 & & 253 & 162 \\
\hline 62 & Mittasēna & 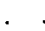 & . . &. & & & & 1 & 0 & 0 & 254 & 163 \\
\hline \multirow[t]{9}{*}{63} & Six Damilas : ${ }^{36}$ & • & . & & & & & & & & & \\
\hline & Pandu . . & • & . & . & & & & 5 & 0 & 0 & 255 & 164 \\
\hline & Pãrinda . . & 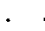 & . & . & & & & 3 & 0 & 0 & 255 & 164 \\
\hline & Khudda-Pārinda & & & & & & & 16 & 0 & 0 & 255 & 164 \\
\hline & Tiritara . . & & & 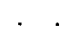 & & & & & 2 & 0 & 256 & 164 \\
\hline & Dãthiya . . & . & - & . & & & & 3 & 0 & 0 & 256 & 164 \\
\hline & Pițhiya. . . & . & .. & 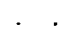 & & & & & 7 & 0 & 256 & 164 \\
\hline & & & & & $(51$ & $9 \quad 1)$ & & 51 & 9 & 1 & & \\
\hline & & & & & $(996$ & $612)$ & & 993 & 0 & & & \\
\hline 64 & Dhātusēna & - & - & - $\cdot$ & & & & 18 & & & 261 & xxxii \\
\hline
\end{tabular}


Dipavamsa (see the note on p. 5 above): they suggest that he had the Dipavarisa before him as he wrote. Similar instances, more or less pointed, are found under Nos. $21,22,39$ to 45 , and 49 ; and perhaps I may have overlooked others. Those under Nos. 41 and 49 seem particularly instructive.

4.- No. 13 : Ëlära. - M. describes him as a Damila : D. does not mention this.

5.- No. 14 : Abhaya-Duțhagāmani.-D. gives his double name in 19. $23:$ M. tells us that he was at first named Abhaya (T., 97 ; W., 62) or Gämani-Abhaya (T., 135; W., 87), and that he acquired the appellation Dutṭhagāmani by an act of disrespect to his father (T., 145; W., 93) : it seems to use only the name Duțthagämani for him as king. D. says plainly that he reigned for 24 years : M. expresses it by making him say, in his dying speech (T., 196-7; W., 125-6), that he had celebrated the great Vaiśâkhapūjā 24 times, and had been the patron of the Samgha for 24 years.

6. - No. 16. - D. gives the name as Thūlathana: M. gives Thullatthanaka.

7.- No. 17.- D. gives Lañja-Tissa, with Lañch $a^{\circ}$, Lajji ${ }^{\circ}$, and Lajji ${ }^{\circ}$ as variants, and says that he reigned nava-vassam chha-mäsam cha. MI. gives the name as Lajji-Tissa, and says that he reigned sama nav =attha-mäs $a \dot{m}$ cha.

8. - Mahārattaka : after No. 18. - D. states that he reigned for one day. M., which does not say that, seems to imply that, as soon as he had killed Khalläțanāga, he was slain by No. 19, Vatțagāmani.

9. - No. 19 : Abhaya-Vatțagāmani.- D. gives his double name in 20. 19 : M. gives it at T., 208; W., 132. The name Valagambāhu seems not to occur in either D. or M. : it is, I believe, established by other works. The Polonnaruva inscription of the year 1708 (p. 329 above) appears to give the name as Valagam-Abhã (= Abhaya). Regarding the broken nature of his reign, first for 5 months, and then, after an interval of 14 years, 7 months, for 12 years, see note 2 on p. 330 above.

10. - No. 20 : five Damilas. - In 19. 15, D. gives these names as Ālavatta, Sābhiya, Panaya, Palaya, and Däthika : in 20. 15-18, it gives Pulahattha, Bāhiya, Panayamāra, Palayamāra, and Dāṭiya, Dāthika. M. gives the names as Pulahattha, Bāhiya, Panaya- or Panayamāra, Pilayamāra, and Dāthiya. The Kalyāṇi inscription gives the last name as Dàdhiya : see note 2 on page 330 above.

11.- No. 21 : Abhaya-Vatțagāmani.-Turnour's table here gives 12 years, 5 months; in addition to showing the 5 months under No. 19. The words of the verse in M. are practically exactly the same, with some transpositions, as in the verse in $\mathrm{D}$.

12. - No. 22. - M. gives the first part of the name as Mahāchūla or "la. Here, again, the verse is practically exactly the same in both D. and $\mathbf{M}$.

13.- After No. 24: Siva and four successors. - These were paramours of No. 25, Anulā : she poisoned first her husband, No. 23, Chōra-Nāga, and then No. 24, Tissa, son of No. 22, Mahāchūli-Tissa: then, raising Siva and the others to the throne in succession, she poisoned each of 
them she then reigned for four months, enjoying the promiscuous society of thirty-two other men. Turnour did not show Siva, etc., separately, and assigned the whole period to Anulā and he entered it as 5 years, 4 months, instead of 4 years, 3 months, which are the figures given by $M$. against 4 years according to $\mathrm{D}$.

14 - Niliya Damilaräja: in the same place - D. says that his name was Niliya, and he was known as Damilarāja M. says that he was a Damila and a Paurōhita Brāhman. D. says that he reıgned tẽ mäsam: M says chham mäsam

15 - No. 29: Abhaya Āmandagāmanı.- Turnour's translation gives "eight years and nine months": and Wijesinha has reproduced that. But the text has nava vassän attha māse ; in accordance with which, Turnour has duly shown 9 years, 8 months, in his table: the same reading is given by $S$. and $B$ 's text.

16. - No 30 : Kanırajānu-Tissa. - The first part of the name is given as alco Kanījānu by M. : the second part is supplied by M., but seems to be mentioned in a various reading of $D$.

17 - No. 32 . Sìvall-Rēvati. - The second part of the name is given in only $\mathrm{D}$.

18 - No. 33 ; Ilanäga - $M$ states something which 15 not mentioned or hinted at in D. : it says that Ilanāga was seized, and imprisoned in his own palace, by some of the Lambakannas, who proceeded to administer the government; he escaped, crossed the sea, and remained absent for 3 years; then he returned, and recovered the sovereignty it concludes the account of him by telling us that "thus he relgned at Anurädhapura 6 complete years". Turnour, in his original table, assigned to Ilanāgd a reign of 6 years, including the 3 years of his absence In his revised table, while still allowing 6 years to Ilanāga, he introduced the "interregnum" of 3 years and he apparently did so as a help towards reducing to four years an 'adjustment' of twelve years which he had previously made in the initial date of No 54, Mahāsēna. On the whole, the entry seems to be justified by the general purport of the narrative in M. also, I have no desire to enhance the case aganst Turnour's results ' so $I$ adopt it

19 - No. 35 - Yasalāla-Tissa - D. says that he reigned satta mās $=$ attha vassān Turnour's text of M. gives sattattha-vass attha-mäsēhi, in which there is obviously something wiong, if only because the metre is faulty S. and B.'s text gives satta-vass-attha-mäsêht.

20. - No 37. Vasabha. - That he was a Lambakanna, is added by M.

21 - No. 39: Gajabähukagāmanı. - In D, the years of thıs king's reign are stated as dvēvissatı in 22. 14, and dvāvissa in 22. 28. Turnour's text of M. says $d v \tilde{a} d a s a$ and he has shown 12 years in his table. S. and B 's text, however, has bãvisa, 'twenty two.' Here, there is something dublous: because the form $b \bar{a} \imath \bar{s} s a$ is foreign to the language of the Mahāvamsa: elsewhere, in every case that I can find, Mahānāma presents only $d v \bar{a}$ or $d v e$, and does not use the $b \bar{a}$ corruption of $d v \imath: b \bar{a} v \bar{\imath} s a$ must be regarded as a correction made by some late reviser. At the sdme time, I understand that at least one manuscript of $\mathrm{M}$. has dvãvisa : so, in view of the double statement in I., it seems best to accept 
22 years. With $d v \bar{a} v \bar{i} s a$ instead of $d v \bar{a} d a s a$, the verse in M. is identical with D., 22. 28.

22. - No. 40: Mahallanāga. - The verse in M. which states the length of his reign is practically identical with D., 22. 29.

23. - No. 4I: Bhātu- or Bhātika-Tissa.- The verse in M. which states the length of his reign is identical with D., 22 . 30 ; including even the excess of one syllable (so exceptional in M.) in the first päda.

24. - No. 42: Kanittha-Tissa. - D. says that he reigned atthärasāni vassāni in 22. 25, and atthārasa samā in 22. 31. Turnour's text of M. gives exactly the same verse with D., 22. 31 : and Turnour translated "eighteen". Wijesinha corrected that into "twenty-eight". And S. and B.'s text has atthärnsa. Those editors, however, have mentioned the reading attharasa in a footnote : and it appears to be given in at least one manuscript. In these circumstances, I prefer to take 18 years.

25. - No. 43: Khujjanāga. - D. gives the name as Khujjanāga : M. gives Chuddanāga according to Turnour, but Chūlanāga according to Wijesinha. Fixcept for the difference in the form of the name, the verse in $M$. is identical with D., 22. 32 .

26. - No. 44: Kuñjanāga.-D. gives the name as Kuñjanāga, with the variants $K u n ̃ c h a^{\circ}, K_{u j j a}{ }^{\circ}$, and $K h u j j a a^{\circ}$ : M. gives it as Kuddanāga. Except for the differences in the forms of the names of the two brothers, the verse in M. appears to be identical with 1), 22. 33: Turnour's ghätiyakärayi seems to be a mistake for the ghätiya bhätikam of D.

27.- No. 46: Tissaka. - D. mentions this king only as Tissaka : M. gives his name as 'Tissa, and says that he acquired the appellation Vōhāraka by setting vōhära, 'judicial business,' free from himsā, 'hurting, killing, or perhaps torture.' D. places No. 47, Abhaya, before No. 46, Tissaka, and describes Tissaka as the younger brother of Abhaya; while M. describes Abhaya as the younger brother : there is no apparent way of deciding between the two: so I follow M., in order to avoid altering Turnour's order unnecessarily.

28. - No. 47: Abhaya. - D. gives this name as Abhaya: M. gives it as Abhayanāga. D. says that he reigned dvāvisa vassāni: M. says attha vassāni. For another note about this king, see the preceding remark.

29.-- No. 49: Vijayakumāraka. - If, as seems likely, Turnour's apachchayē is a mistake for achchayè, the verse in M. is exactly identical with D., 22. 51, including an excess of one syllable in the first pāda.

30.- No. 50 : Asanga- or Samgha-Tissa. - D. gives both forms of the name: M. gives only the second. M. supplies the information that he and his two successors were Lambakannas.

31.- No. 52: Abhaya-Mēghavaṇạa. - His other name, Gōthābhaya, is supplied by $\mathrm{M}$.

32. - No. 53 : Jețtha-Tissa. - Turnour's translation gives "twelve years": and that was reproduced by Wijesinha. But Turnour's text has dasa vassāni: and that is also the reading in $\mathrm{S}$. and B.'s text. In his table, Turnour correctly showed 10 years.

33. - No. 55. - Siri-Mēghavanna. - Turnour attached to this king's name the prefix Kitti : but it is not supported by the text of $M$. ; nor, apparently, by the Chinese account (loc. cit., note 1 on p. 342 above). 
34 - No 60 Sotthisena - He was put to death on the same day on which he succeeded to the throne I follow Turnour in assigning to him a reign of one day

35 - No 61 Jantu - The text says samvachchhare mato, " he died in, or at (the end of), the year" I follow Turnour in assigning to him a reign of one year

36 - No 63 six Damilas - Turnour, omittıng Tiritara, gave five rulers, as follows Pandu, 5 years, 'Parında Kuda,' 16 years, Khudda Parında, 2 months, Dathiya, 3 years, Pithiya, 7 months I follow Wijesinha's translation, which seems plainly correct, and involves only two reasonable emendations of Turnour's text

\section{POSTSCRIPT}

On the day after receiving final proof of the preceding paper in pages, I learnt that Professor Geiger s critical edition of the Mahavamsa had been published I need hardly say that, if I had known that his work was so near completion, I should have held my paper over, so as to be able to quote the detalls for the Mahavamsa by chapter and verse as given in his text

It is a gratification to me to find that, amongst the doubtful readings in respect of which I had to come to a decision, there are only two cases in which the figures set out in my table differ from those given by Professor Gergel s text They are as follows -

No 11 Sena and Guttaka - Below his text of M, 21 11, Professor Gelger has notel the readings duve dvadasa rassan and "visati ${ }^{\circ}$ But he has chosen a third reading, "duavisa", "the two (together) for 22 years"

Mixed up with this question, there is that of the interval (see p 340 above) from some point in the time of Devanampiya Tissa to a point in the time of Dutthagaman1, specified in the "prophecy" about the bulling of the Mahathupa Here, under M, 27 6, Professor Geiger has noted the readings chattalisa satam vassam, " 140 years," and chhachattalisa satam vassam, " 146 years" But he has preferred a third reading, chhattimsa sata iassani, " 136 years," which was not known to me And in accordance with this he has said (p 368, where "Elara 40 years" is a misprint for "Elara 44 years") that in M, 21 11, duve dvadasa vassan seems to be preferable, because, if we assign only 12 years to Sena and Guttaka, the unterval is 136 years from [the beginning of the reign of] Devānampiya Tissa to [the beginning of the rergn of] Dutthagaman1, and chhattimsa sata vassani in $\mathrm{M}, 276$, is in agreement with that

'The "prophecy' may certainly be understood in that way and we may, no doubt, dismiss the reading which gives " 140 years" And, if this view of the case is accepted, then my totals for the Mahavamsa are to be reduced by 8 years from below No 13 to the end It may, indeed, be pointed out that if we accept 22 years for Sena and Guttaka, then the total inteival is 146 years, in agreement with which we have a reading of M , 276 , as noted above But it must also be remarked that the chhattmsa sata rassun, " 136 years," selected by Professor 
Geiger, is grammatically as well as metrically more correct than chhachattälisa-satam vassam: the latter may be not unfairly regarded as a correction made to suit a corruption of dvādasa into dvāvisa in M., 21. 11 .

No. 17 : Lañja-Tissa.- In M., 33. 28, Professor Gelger has given the reading $s a m \tilde{a}$ nav $=$ addha-masam $c h a$, "9 years and half a month;" noting, as various readings, ${ }^{\circ} n a v=a d d h \alpha^{\circ}$ and ${ }^{\circ}$ nav $=a t t h a^{\circ}$.

If we accept the selected reading, my totals for the Mahāvamsa are to be further reduced by 7 months, 15 days, from below No. 18 to the end. But $I$ would suggest that the three readings may be corruptions of an original samā nava chha-māsam cha, "9 years and 6 months," which would match the statement in the Dipavamsa. In that case, only two months are to be deducted, onwards from the point indicated. 